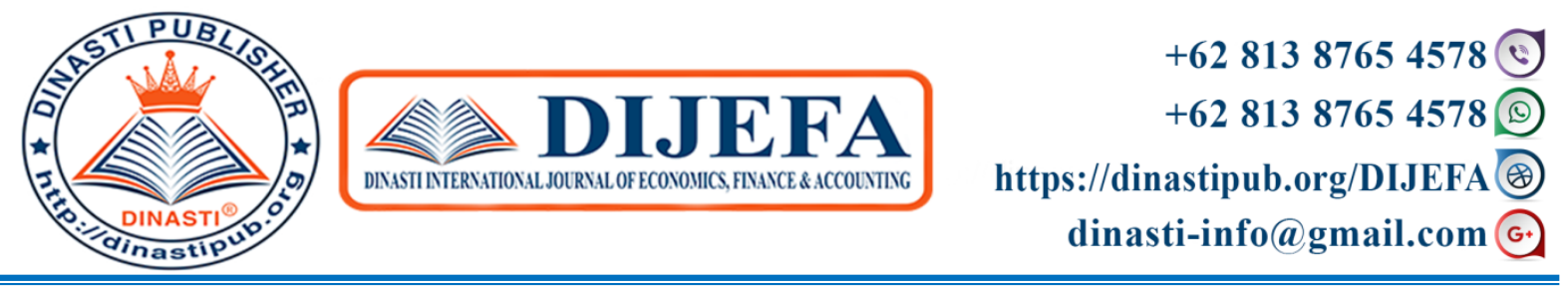

\title{
THE EFFECT OF LIQUIDITY AND WORKING CAPITAL ON CORPORATE VALUES WITH PROFITABILITY AS MODERATING VARIABLES IN MANUFACTURING COMPANIES LISTED ON IDX
}

\author{
Hanna Pratiwi ${ }^{1)}$, Ronni Andri Wijayaa ${ }^{2)}$, Desi Permata Sari ${ }^{3)}$, Riska Maiputri Yengsih ${ }^{4)}$ \\ 1) 2) 3) 4) Universitas Putra Indonesia "YPTK", Padang, Indonesia
}

\begin{tabular}{|c|c|}
\hline $\begin{array}{l}\text { ARTICLE INFORMATION } \\
\text { Received: 05 March } 2020 \\
\quad \text { Revised: 16 March } 2020 \\
\quad \text { Issued: 22 March } 2020 \\
\text { Corresponding author: } \\
\text { Desi Permata sari } \\
\text { E-mail: } \\
\text { Desipermatasari735@gmail.com }\end{array}$ & $\begin{array}{l}\text { Abstract: This study aims to examine and analyze the } \\
\text { effect of Liquidity (X1) and Working Capital (X2) on } \\
\text { Company Value (Y) with Profitability (Z) as a } \\
\text { moderating variable. The study was conducted on } \\
\text { manufacturing companies listed on the Indonesia } \\
\text { Stock Exchange with a research period of 2014-2018. } \\
\text { The sample selection method used is porpusive } \\
\text { sampling and obtained as many as } 22 \text { manufacturing } \\
\text { companies as samples with } 110 \text { observations. Based } \\
\text { on the partial test results there is a significant effect } \\
\text { between liquidity on firm value, there is no influence } \\
\text { between working capital on firm value. Liquidity and } \\
\text { working capital together have a significant effect on } \\
\text { firm value. Profitability is not able to moderate } \\
\text { liquidity to the value of the company. Profitability is } \\
\text { able to moderate working capital to the value of the } \\
\text { company. Simultaneously liquidity and working } \\
\text { capital have a significant effect on firm value. The } \\
\text { contribution of the independent variable that is } \\
\text { liquidity and working capital in influencing the } \\
\text { dependent variable that is the value of the company is } \\
\text { 87.23\%.. } \\
\text { Keywords: Liquidity, Working Capital, Company } \\
\text { Value, Profitability. }\end{array}$ \\
\hline
\end{tabular}

\section{INTRODUCTION}

The phenomenon that occurs, the existence of liquidity and working capital is a serious problem and is an aspect faced by the company. Many companies went bankrupt (liquidated) due to these conditions. Thus, the influence of liquidity and working capital of the company is very important to know the profitability and financial condition of the company and then linked to the financial situation in the future. For this reason, it is necessary to have good planning and control in available financial management, assuming 
every rupiah in company finance embedded in assets must be used as efficiently as possible so as to produce efficient corporate value. Even, there are still many companies that survive and are able to generate profits. With the ever-changing economic conditions, companies must be able to create an advantage that can make it survive in the midst of a crisis that is reflected in the value of the company by looking at stock prices. According to Ifin (2016), investor perceptions of the level of success of the company in managing resources are reflected in the company's stock price.

According to Suffah and Riduwan (2016), the value of a company is an investor's perception of the company, which is often related with stock prices. Explain that one of the things that investors consider in investing is the value of the company where the investor will invest. For creditors the company's value is related to company liquidity.

According to Hery (2016), liquidity ratio is a ratio that can be used to measure how far the company's ability to pay off short-term obligations that will due soon. Liquidity is considered able to influence the value of the company, the higher the level of liquidity, the market will put trust in the company, because the company can maintain the level of liquidity, which means the company has good performance, so that it will increase the value of the company (Efendi 2016). Sari (2017) liquidity refers to a company's ability to meet its short-term obligations.

Another factor that influences company value is working capital. Fahmi (2016: 100) working capital is a company's investment in short-term assets of cash, securities, inventories and receivables. Research conducted by Fatahillah (2015) found that there was a positive and significant influence between working capital and firm value. This means that the decision to use the right working capital can maximize profits and increase company value.

\section{LITERATURE REVIEW}

\section{The Value of Company}

According to Pertiwi et al (2016), high company value will make the market believe not only in the company's current performance. However, Working Capital to Company Value is also in the company's prospects in the future. One of the prosperity of shareholders is seen from the high and low value of the company.

\section{Liquidity}

According to Kasmir (2015), liquidity can be interpreted as the level of a company's ability to be able to pay its debts that are due date. Liquidity has a relationship with the value of the company, which the company is considered whether or not it is able to repay loans provided by creditors. If the value of the company is not implied, then investors will value the company with a low value. In the study of Du et al (2016), the results show that Liquidity affects Company Value.

\section{Working Capital}

According to Arfan et al (2016: 98), working capital is assets owned by companies that are used to carry out business activities or finance company operations without sacrificing other assets with the aim of obtaining optimal profits. Working capital has a relationship with the value of the company because the company requires working capital as one of the important aspects needed by the company to finance its operational activities and 
to develop its business. The decision to use the right working capital can maximize profits and increase company value.

\section{Profitability}

According to Gitman and Zutter (2015), profitability is a company's ability to generate profits during a certain period at a certain level of sales, assets, and share capital. Liquidity has a close relationship with the company's value and profitability because it is one of the factors that influence the value of the company to be able to generate large profits, so the company will be assessed to provide good benefits for the management and shareholders.

Working capital has a relationship with company value and profitability, because the company requires working capital as one of the important aspects needed by the company to finance its operational activities and business development. Profitability is considered very important to show the effectiveness of management in carrying out its operations.

\section{RESEARCH METHODS}

In this study, the authors use secondary data types. The data source used in this study was obtained from the annual financial statements of companies listed on the Indonesia Stock Exchange (IDX) during the 2014-2018 period published on the IDX website (www.idx.co.id).

The population in this study amounted to 165 companies listed on the Indonesia Stock Exchange (IDX) with the research year being 2014-2018. The sample in this study was 22. The company was taken randomly or randomly at a publicly listed company listed on the Indonesia Stock Exchange. With a sample of 22 companies in a period of 5 years, it means that the data processed is 110 data.

The dependent variable in this study is firm value. Firm value is measured using PBV, by comparing the stock price per sheet with the book value per sheet (Arfan et al (2016: 98). The independent variable in this study is liquidity and working capital. Liquidity is a ratio that can be used to measure how far the company's ability to pay off short-term obligations that will soon be due Working capital is assets owned by the company that are used to carry out business activities or finance the company's operations without sacrificing other assets with the aim of obtaining optimal profits.

This study used profitability variable. Profitability is describing the ability of companies to get profits through all the capabilities of existing resources such as sales, cash, capital, number of employees, number of branches, and so on. It's measured by using ROA by comparing net income after tax with total assets.

$$
\begin{aligned}
& y=a+\mathrm{b} 1 \mathrm{X} 1+\mathrm{b} 2 \mathrm{X} 2+\varepsilon \\
& y=a+\mathrm{b} 1 \mathrm{X} 1+\mathrm{b} 2 \mathrm{X} 2+\mathrm{b} 1 \mathrm{X} 1 * \mathrm{z}+\mathrm{b} 2 \mathrm{X} 2 * \mathrm{z}+\varepsilon
\end{aligned}
$$

\section{FINDINGS AND DISCUSSION}

Descriptive statistics are used to provide descriptive data seen from the mean, standard deviation, maximum, minimum, mean and standard deviation.

Table 1 : Deskriptive Statistics

\begin{tabular}{ccccc}
\hline \hline & Y_NIL_PER & X1_LIKUIDITAS & X2_MOKERJA & Z_PROFIT \\
\hline \hline Mean & 7.743273 & 2.732373 & 4.453855 & 0.132373
\end{tabular}




\begin{tabular}{lcccc} 
Maximum & 82.44000 & 8.638000 & 35.48200 & 0.527000 \\
Minimum & 0.000000 & 0.514000 & -14.91500 & 0.009000 \\
Std. Dev. & 13.50171 & 1.694024 & 7.772369 & 0.111668 \\
Observations & 110 & 110 & 110 & 110 \\
\hline
\end{tabular}

Source : Processed data Using Eviews 10

Based on table 1 above, information is obtained that the number of samples consists of 22 samples and the amount of data entered in this test is 110 data. Company Value Variable (Y) as the dependent variable has the lowest value of 0.000000 and the highest value recorded is 82.44000 with an average Company Value of 7.743273 with a standard deviation of 13.50171 .

The independent variable in this study, namely Liquidity (X1) has the lowest value of 0.514000 and the highest value is recorded at 8.638000 with an average variable of 2.732373 and a standard deviation of 1.694024. Working Capital Variable (X2) has the lowest value of -14.91500 and the highest value of 35.48200 , with an average variable of 4.453855 and a standard deviation of 7.772369 . The moderating variable namely Profitability (Z) has the lowest value of 0.009000 , and the highest value of 0.527000 with an average variable of 0.132373 and with a standard deviation of 0.111668 .

Table 2: Test Result of Chow-Test

\begin{tabular}{lrrr}
\hline \hline Effects Test & Statistic & d.f. & Prob. \\
\hline \hline Cross-section F & 19.598291 & $(21,86)$ & 0.0000 \\
Cross-section Chi-square & 193.091483 & 21 & 0.0000 \\
\hline \hline
\end{tabular}

Source : Processed data Using Eviews 10

Based on the Chow Test results without estimating the interaction of moderation using Eviews 10, a probability of 0.0000 is obtained. Because the probability value is smaller than the significant level $(\alpha=0,05)$, it can be concluded that the hypothesis is accepted, so a better estimate used in this model is the fixed effect model. Because the model chosen was the fixed effect model, the test continued with the Hausman test.

Table 3 : Test Result of Hausman-Test

\begin{tabular}{lrrr}
\hline \hline Test Summary & Chi-Sq. Statistic & Chi-Sq. d.f. & Prob. \\
\hline \hline Cross-section random & 36.029233 & 2 & 0.0000 \\
\hline \hline
\end{tabular}

Source : Processed data Using Eviews 10

Based on the results of the thirst test without estimating moderation by using Eviews, a probability of 0.0000 is obtained. The probability value is smaller than the significant level $(\alpha=$ 
Table 4 : Result of Estimation of Fixed Effect Panel Regression X1, X2 to Y Dependent Variable: Y_NIL_PER

\begin{tabular}{ccccc}
\hline \hline Variable & Coefficient & Std. Error & t-Statistic & Prob. \\
\hline \hline X1_LIKUIDITAS & -0.325916 & 0.113740 & -2.865458 & 0.0052 \\
X2_MOKERJA & 0.041063 & 0.036209 & 1.134030 & 0.2599 \\
LUKUIDITAS_PROFI & & & & \\
TABILITAS & -0.406112 & 0.724463 & -0.560570 & 0.5765 \\
MOKERJA_PROFITA & & & & \\
BILITAS & 2.084828 & 0.352128 & 5.920651 & 0.0000 \\
C & 8.450911 & 0.398623 & 21.20026 & 0.0000 \\
\hline \hline & Effects Specification & & \\
\hline \hline Cross-section fixed (dummy variables) & & \\
\hline \hline R-squared & 0.899225 & Mean dependent var & 17.13360 \\
Adjusted R-squared & 0.872273 & S.D. dependent var & 16.74170 \\
S.E. of regression & 4.212586 & Sum squared resid & 1526.146 \\
F-statistic & 33.36451 & Durbin-Watson stat & 1.910324 \\
Prob(F-statistic) & 0.000000 & & & \\
\hline \hline
\end{tabular}

Source : Results of processed panel data regression using Eviews 10

The results of the first hypothesis testing using liquidity variables have a regression coefficient of $-0,325916$ and ${ }^{\mathrm{t}}$ statistic of $-2,865458$ with a probability value of 0,0052 smaller than 0,05 or $(0,0052<0,05)$, it can be concluded that the liquidity variable has a significant negative effect on the value of the company in publicly listed companies listed on the Indonesia Stock Exchange in the period 2011-2018. The results of this study are in line with the results of research conducted by the results obtained are in line with the results of research from. Research from Putra and Lestari (2016) says that liquidity has a significant effect on company value. These results are different from Indiyani's research (2917) which found that liquidity had no significant effect on firm value.

The results of the second hypothesis testing using working capital variables have a regression coefficient of 0,041063 and a statistical value of 1.134030 with a probability value of 0.2599 greater than 0.05 or $(0.2599>0.05)$, it can be concluded that Working capital variable does not significantly influence the value of the company in publicly listed companies listed on the Indonesia Stock Exchange in the period 2011-2018. The results of this study are in line with the study of Warouw (2016) stating that Working Capital has no effect on Company Value. But not in line with the results of research Agusentoso (2017) and Indriyani, et al (2018) who found that working capital has a significant effect on firm value.

The results of testing the third hypothesis by using the variable liquidity and working capital together with having a value of $0,00000<0,05$ and showing the value of $F_{\text {count }}$ 33,36451 then the authors can conclude that the Liquidity variable $\left(\mathrm{X}_{1}\right)$ and the Working Capital variable $\left(\mathrm{X}_{2}\right)$ together positive and significant effect on Company Value $(\mathrm{Y})$.

The results of the fourth hypothesis testing using the variable liquidity on firm value with profitability as a moderating variable that has a statistical $t$ test Liquidity variable is - 
0.560570 with a significant level $(0.5765>0.05)$, meaning that partially there is no effect of Liquidity on Company value with profitability as moderating.

The fifth test results using the variable working capital to the value of the company with profitability as a moderating variable that has the statistical $t$ test results of the Working Capital variable is 5.920651 with a significant level $(0.0000<0.05)$, meaning that partially there is a positive influence and significant between Working Capital and Firm Value and profitability as a moderating factor.

Based on the estimation results in table 4 it is known that the Adjusted R-squared value obtained is 0.872273 or $87.23 \%$. This indicates that the contribution of the independent variable, Liquidity with Working Capital, to the dependent variable, which is the Company Value, is $87.23 \%$ and the remaining $12.77 \%$ is determined by other variables not analyzed in the model in this study such as debt policy, capital structure.

\section{CONCLUSION AND SUGESTION}

Based on data analysis, interpretation, and discussion of research results that have been submitted previously, it can be concluded several conclusions as follow:

1. From the partial test results there is a significant effect Liquidity on Company Value in Manufacturing Companies listed on the Indonesia Stock Exchange in 2014-2018.

2. From the partial test results there is no influence of Working Capital on Company Value in Manufacturing Companies listed on the Indonesia Stock Exchange in 2014-2018.

3. Simultaneous test with panel regression equation can be concluded that the Liquidity and Working Capital variables together have a positive and significant effect on Company Value in Manufacturing Companies listed on the Indonesia Stock Exchange in 20142018.

4. From the partial test results there is no effect of Liquidity on Company Value by being moderated by Profitability on Manufacturing Companies listed on the Indonesia Stock Exchange in 2014-2018.

5. From the test results partially there is a significant influence of Working Capital on Company Value by being moderated by Profitability on Manufacturing Companies that are listed on the Indonesia Stock Exchange in 2014-2018.

\section{REFERENCE}

Agusentoso Randhy. 2017. Pengaruh Struktur Modal, Perputaran Modal Kerja dan Profitabilitas Terhadap Nilai Perusahaan (PBV) Studi Kasus Perusahaan Pertambangan Dan Energi di BEI. Vol 1 no 4.

Arfan, dkk. (2016). Analisa Laporan Keuangan. Cetakan Pertama. Medan: Penerbit Madenatera

Effendi, Muh. Arief. 2016. The Power Of Corporate Governance: Teori dan Implementasi. Jakarta: Salemba Empat.

Fatahillah, Hidayati. 2015. Pengaruh Efisiensi Modal Kerja, Likuiditas, Aktifitas dan Solvabilitas Terhadap Profitabilitas Pada Perusahaan Manufaktur di BEI. Skripsi: S1 Fakultas Ekonomi UNISMA, Malang

Hery. 2016. Analisis Laporan Keuangan. Jakarta : Grasindo 
Indriyani, Eka. 2017. Pengaruh Ukuran Perusahaan dan Profitabilitas Terhadap Nilai Perusahaan. Akuntabilitas: Jurnal Ilmu Akuntansi Volume 10 (2), Oktober 2017 PISSN: 1979-858X; E-ISSN: 2461-1190 Page 333 - 348.

Indriyani Ayu, Paramita Patricia Dhiana. 2018. Pengaruh Perputaran Modal Kerja Dan Net Profit Margin (NPM) Terhadap Nilai Perusahaan Dengan Profitabilitas Sebagai Variabel Moderating Pada Perusahaan Farmasi Yang Terdaftar Di Bursa Efek Indonesia Periode 2012-2016: Journal Off Accounting Universitas Pandanaran Semarang

Irham Fahmi. 2016. Pengantar Manajemen Keuangan, Cetakan kelima, Alfabeta, Bandung

Kasmir. 2015. Analisis Laporan Keuangan. Jakarta: Rajawali Pers

Lawrence J. Gitman and Chad J. Zutter. 2015. Principle Of Managerial Finance, Fourteenth Edition. Singapore: Pearson Education

Putra, AA Ngurah dharma adi, lestari, putu vivi. 2016. Pengaruh Kebijakan Dividen, Likuiditas, Profitabilitas Dan Ukuran Perusahaan Terhadap Nilai Perusahaan. E-Jurnal Manajemen Unud

Sari dan Hidayat. 2017. Pengaruh Struktur Modal, Likuiditas terhadap Profitabilitas Perusahaan Makanan dan Minuman di BEI. Jurnal Ilmu dan Riset Manajemen. Vol. 6. No. 6. Sekolah Tinggi Ilmu Ekonomi Indonesia (STIESIA) Surabaya

Suffah, Roviqotus dan Akhmad Riduwan. 2016. Pengaruh Profitabilitas, Leverage, Ukuran Perusahaan Dan Kebijakan Dividen Pada Nilai Perusahaan. Jurnal ilmu dan riset akuntansi volume 5 nomer 2, februari 2016

Warouw, Christiana, Nangoy Sintje, Saerang Ivonne S. 2016. Pengaruh Perputaran Modal Kerja Dan Profitabilitas Terhadap Nilai Perusahaan Pada Perusahaan Farmasi Di Bursa Efek Indonesia. Jurnal Berkala Ilmiah Efisiensi Universitas Sam Ratulangi Manado, vol. 16 no. 02 